\title{
Impact of COVID-19 on Global Stock Market Volatility
}

\author{
Teresia Angelia Kusumahadi ${ }^{1+}$ and Fikri C Permana ${ }^{1}$ \\ ${ }^{1}$ Atma Jaya Catholic University of Indonesia, Indonesia
}

\begin{abstract}
This study aims to examine the impact of COVID-19 on stock return volatility in 15 countries worldwide. Using daily data from January 2019 to June 2020, we find that changes in exchange rates have negatively affected stock returns in most countries. We also identify structural changes over the observation period; these structural changes occur not just after the first case of COVID-19 but also earlier in the period. Based on threshold generalized autoregressive conditional heteroskedasticity regressions, we find evidence that the emergence of COVID-19 affected stock return volatility in all observed countries except the United Kingdom. Furthermore, we find that the presence of COVID-19 in a country positively affects return volatility. However, the magnitude of this effect is small in every observed country. This finding suggests the need for in-depth studies of other factors that affect stock return volatility besides the occurrence of COVID-19.
\end{abstract}

Keywords: COVID-19; stock return; volatility; structural change; ordinary least squares; threshold generalized autoregressive conditional heteroskedasticity model

JEL Classifications: C58, F36, F65, G15

Received 12 November 2020, Revised 15 January 2021, Accepted 26 January 2021

\section{Introduction}

In 2019, the market expected the tensions associated with the United States-China trade war, the United States presidential election, and Brexit to be the main factors that would affect global financial markets in 2020. At the end of 2019, however, the world was shocked by an unknown disease that attacks the respiratory system. This disease first appeared in Wuhan City, Hubei Province, China, and has continued to spread to this day. At first, it was known as the novel coronavirus (i.e., 2019-nCoV), but on February 11, 2020, the World Health Organization (WHO) named it coronavirus disease 2019 (COVID-19). From the date of its first appearance through the end of June 2020, more than ten million people in more than 200 countries contracted COVID-19, and 503,862 of them have died (World Health Organization, 2020).

\footnotetext{
+Comesponding Author: Teresia Angelia Kusumahadi

Lecturer, Faculty of Economics and Business, Atma Jaya Catholic University of Indonesia, Jalan Jenderal Sudirman No.51, Jakarta 12930, Indonesia. Email: teresia.kusumahadi@atmajaya.ac.id

Co-Author: Fikri C Permana

Lecturer, Faculty of Economics and Business, Atma Jaya Catholic University of Indonesia, Jalan Jenderal Sudirman No.51, Jakarta 12930, Indonesia. Email: fikri.permana@atmajaya.ac.id
} 
To prevent further spread, the Chinese government banned all access to the city of Wuhan, whose population is greater than eleven million, in January 2020. Additionally, the government restricted entry and exit access to several cities in Hubei. This policy was effective. In March 2020, China reported no new COVID-19 cases. However, COVID-19's spread was inevitable. Today, many countries are struggling to deal with COVID-19, and the WHO has declared it to be a pandemic. Figure 1 shows that almost all countries are affected by COVID-19.

Figure 1. COVID-19 map as of August 25, 2020

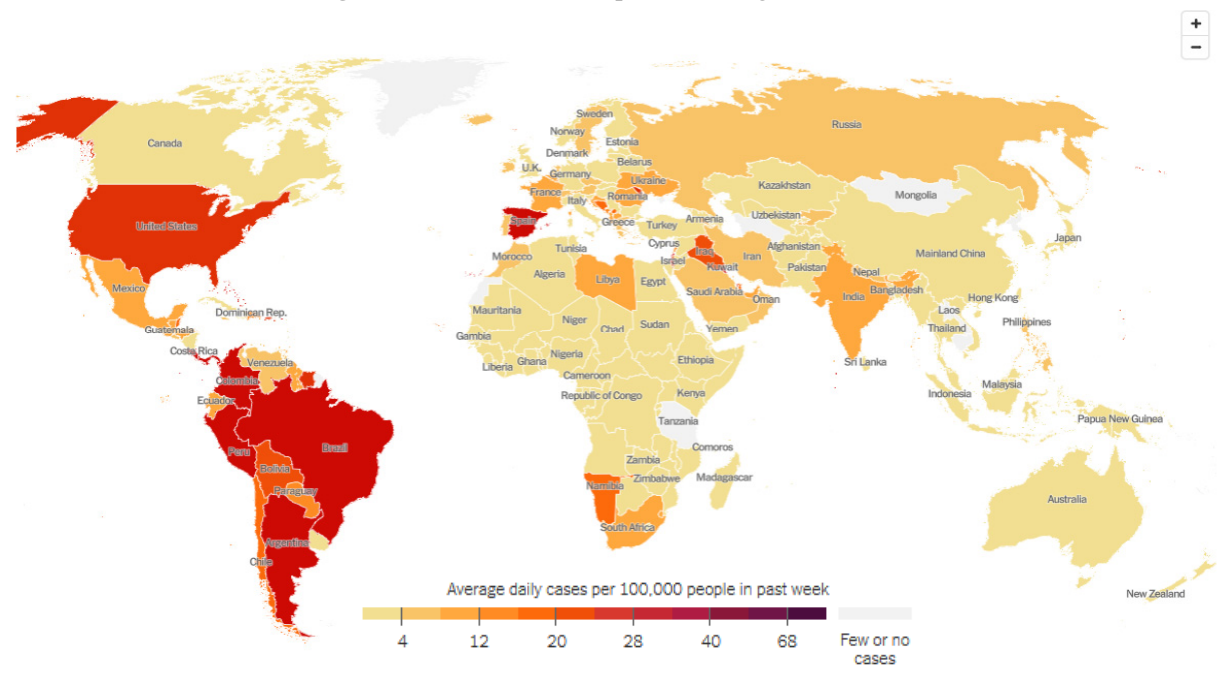

(Source) New York Times, 2020

The spread of COVID-2019 will either directly or indirectly impact not only the health conditions of the global community but also the economy. This inevitability is reflected in the statement by the President of China, Xi Jinping, on February 15, 2020, that "coronavirus will have a relatively large impact on the economy and society." Xi Jinping's statement is very reasonable because the virus's spread has forced various cities in China and other countries worldwide to close and stop economic processes, especially production, impacting even the global supply chain. In March 2020, the International Air Transport Association stated that COVID-19 would decrease the number of aircraft passengers and reduce global aircraft industry revenue by $\$ 113$ billion. Similar declines are likely to occur in the global electronics, vehicle, telecommunications, trade, and even agriculture and planting industries.

At the same time, the pandemic's emergence has driven a rapid shift in global financial markets' focus. The main factors behind this market shift are fear and uncertainty. For example, the decline in S\&P 500 index in the last week of February (i.e., from February 24 to 28) alone resulted in a loss of market capitalization of over $\$ 5$ trillion. Decreasing stock prices can show that anxiety leads investors to behave irrationally, causing them to exhibit biases. As a result, stock prices 
diverge, and the resulting stock market behavior tends toward anomalies (Isidore \& Christie, 2018).

Thus, it is not surprising that stock exchanges in various countries affected by COVID-19 declined since the first emergence of the virus through the end of March 2020. From March 2020 through June 2020, stock indexes increased, but they have not yet reached pre-COVID-19 levels.

Figure 2. Changes in the stock indices of several countries affected by COVID-19 (December 31, $2019=100$ )

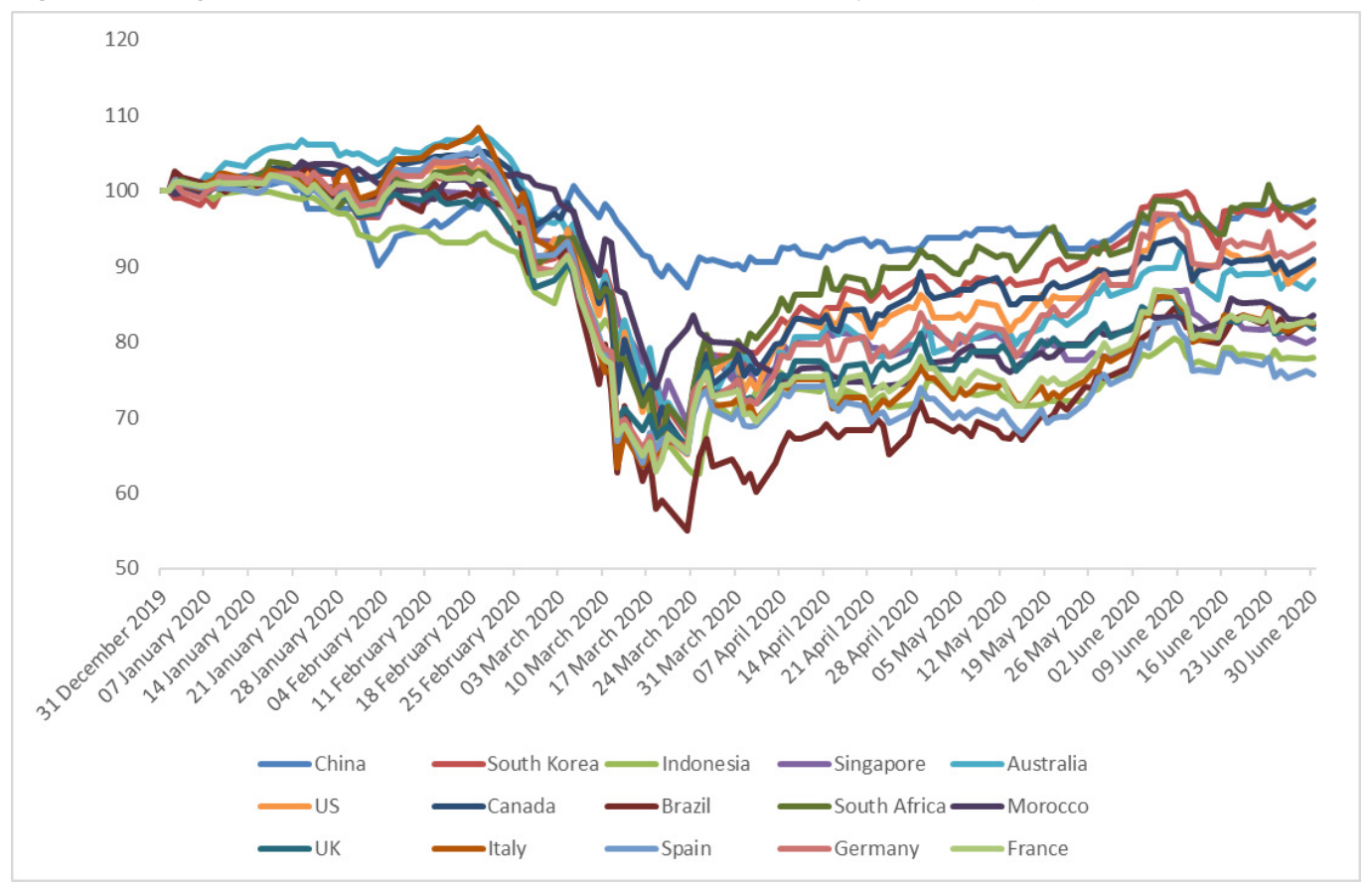

(Source) Authors' calculation using Bloomberg Terminal 2020 data

Figure 2 shows that all countries affected by COVID-19 experienced negative returns. These negative returns offer a strict warning, to which all global economic stakeholders should comply. Given that stock prices are a leading economic indicator, or an indicator that tends to rise or fall in advance of other economic indicators (Bodie, Kane, \& Marcus, 2013), this decline in stock returns may be an important indicator for the overall economy. Furthermore, stock returns are typically highly volatile, meaning that their values change rapidly and unpredictably over time. Stock return volatility is also time-varying such that in one period, large changes may be followed by additional larger changes or small changes may be followed by additional smaller changes (Hill, Griffiths, \& Lim, 2011). These price fluctuations in the market are one indicator used in financial system stability and can serve as an early warning of possible threats to financial stability (Sahel \& Vesala, 2001).

This study examines whether COVID-19 has impacted stock return volatility in several countries 
affected by the pandemic. Using two different approaches, namely, the fundamental equation and the threshold generalized autoregressive conditional heteroskedasticity (TGARCH) model, this study closes a gap in empirical research on COVID-19 and stock volatility, especially in countries in various parts of the world, including Asia, Europe, the Americas, and Africa. We expect that the international community, authorities, and economic agents can use these empirical findings to prepare for unwanted circumstances, especially pandemics. Additionally, this research can contribute to the academic literature on the stock market and financial system stability.

\section{Literature Review}

The stock market responds differently to various different events (Ramiah, 2013). Changes in stock prices over time align with concurrent conditions and information. Internal and external factors can also affect changes in stock prices. The relevant internal factors are fundamental aspects of the company, such as its income and dividends (Al-Tamimi, Alwan, \& Rahman, 2011). Several external factors also impact stock prices, one of which is information or news obtained by investors (Chan, 2003), which can be either positive or negative. Bae and Karolyi (1994) find that negative domestic and foreign news impacts stock prices more significantly than good news does.

These factors are inseparable from investors' reactions to the received information. The behavior of various individual investors develops into collective behavior, including herding behavior. Shiller (2003) also states that investors sometimes overreact to news and sometimes barely react at all (underreact), indicating a bias in stock market investors' behavior.

The outbreak of a disease is a type of the negative news that can impact prices in the stock market. Few studies have investigated the effects of outbreaks on stock markets. However, several studies have examined the impact of severe acute respiratory syndrome (SARS) on stock performance. The SARS outbreak occurred in 2003. Similar to COVID-19, SARS is a respiratory disease that has spread to several countries. Nippani and Washer (2004) examine whether SARS impacted the stock markets in Canada, China, Hong Kong, Indonesia, and the Philippines. By comparing stock indexes during and before the SARS outbreak, they find that SARS had no negative impacts except in China and Vietnam.

Chen, Jang, and Kim (2007) evaluate the impact of the SARS outbreak on hotel stocks in Taiwan. The results show that hotel stocks experienced significant price and income declines during the SARS outbreak. The study also finds that the tourism industry experienced the most significant impact of all sectors, with its share prices decreasing by approximately $29 \%$.

Chen, Chen, Tang, and Huang (2009) conduct another study on the impact of the spread of disease on stock markets. They aim to determine whether the spread of SARS in Taiwan impacted 
several sectors, including the aviation, tourism, retail, and biotechnology sectors, on Taiwan's stock exchange. They observe positive shocks to the returns of biotech stocks but negative shocks to the returns of other stocks.

Albulescu's (2020) study on COVID-19 is the most recent research on this topic. He aims to examine whether the numbers of COVID-19 cases and the resulting death rates within and outside China impacted the financial market volatility index (VIX). Applying a simple regression to data from the period January 20, 2020, to February 28, 2020, he finds that only new cases outside of China impacted the VIX. He also finds that the death rate had a positive and significant impact on the VIX. Other results of this analysis also show that the spread of COVID-19 increases financial market volatility.

Baker et al. (2020) use a text-based method in their research. They try to observe the stock market's reaction to the presence of COVID-19. By evaluating the movement in the United States stock market from 1900 to April 2020, they find that stock market volatility has been greater during the COVID-19 pandemic than it was during the Spanish flu pandemic in 1918-1919 and the influenza pandemics in 1957-1958 and 1968. Moreover, stock market volatility in the United States was much higher during the emergence of COVID-19 than during the emergences of other diseases, such as bird flu, SARS, Middle East respiratory syndrome, and Ebola.

Zeren and Hizarci (2020) also test the impact of COVID-19 on the stock market. Their study includes data from China, South Korea, Italy, Germany, and Spain. Using a cointegration test and data from January 23, 2020, to March 13, 2020, they find a long-term relationship between the number of deaths caused by COVID-19 and the stock markets in all countries in their sample. They also find long-term relationships between some COVID-19 cases and most of the stock markets in their sample.

Liu, Manzoor, Wang, Zhang, and Manzoor (2020) study the short-term impact of COVID-19 on stock markets in 21 affected countries, including Japan, Korea, Singapore, the United States, Germany, Italy, and the United Kingdom. Their data span February 21, 2019, to March 18, 2020. The results show that COVID-19 has negative and significant impacts on returns for the stock markets considered in their study. Additionally, they find that Asian stock markets reacted more quickly to COVID-19 and that some of them are recovering rapidly as well. Investors' fear has proven to be a mediator and transmission channel for COVID-19's effects on the stock market.

\section{Data and Methodology}

For this study, we use daily data from January 1, 2019, to June 30, 2020, with a total of 391 observations. The COVID-19 period is December 31, 2019, to June 30, 2020. Specifically, we use data on stock index returns for 15 countries affected by COVID-19. These countries 
are located in various parts of the world, including Asia, Europe, the Americas, and Africa. We choose these 15 countries based on their having the most cases when this study was initiated (i.e., the end of March 2020) and large market capitalizations. Table 1 lists the stock exchanges used in this study.

Table 1. List of Stock Exchanges

\begin{tabular}{lc}
\hline Countries & Stock Exchanges \\
\hline United States & Dow Jones Industrial Average Index \\
Italy & FTSE MIB Index \\
Spain & IBEX 35 Index \\
Germany & Deutsche Boerse AG German Stock Index \\
China & Shanghai Stock Exchange Composite Index \\
France & CAC 40 Index \\
United Kingdom & FTSE 100 Index \\
Canada & S\&P/TSX Composite Index \\
South Korea & Korea Stock Exchange KOSPI Index \\
Brazil & Ibovespa Brasil Sao Paulo Stock Exchange Index \\
Australia & S\&P/ASX 200 Index \\
Indonesia & Jakarta Stock Exchange Composite Index \\
South Africa & FTSE/JSE Africa Top40 Tradeable Index \\
Singapore & Straits Times Index \\
Morocco & MASI Free Float All Shares Index \\
\hline
\end{tabular}

The data are secondary data obtained from Bloomberg Terminal. We use the Eviews application as a tool for data and research analysis.

The returns used in this study are continuously compounded returns, or log returns, which are calculated as follows:

$$
R=\ln \left(\frac{P}{P_{-1}}\right) \times 100 \%
$$

Note: $R_{i t}=$ return obtained by an investor for stock $i$ in period $t$

$P_{i t}=$ closing price of index $i$ in period $t$

$P_{i t-1}=$ closing price of index $i$ in period $t-1$

The data on continuous compounded returns are used to test the impact of the COVID-19 pandemic on stock return volatility in several countries affected by the disease. In this study, we use two main approaches, which complement each other, to determine whether COVID-19 has significantly affected return volatility. These two methods are the fundamental equation 
and the TGARCH model.

\section{A. Fundamental equation}

Although it is challenging to explain the fundamental equation of stock index movement because it is affected by many factors, Dornbusch, Park, and Claessens (2000) state that fundamental economic conditions contribute to financial market volatility. Furthermore, Engel and West (2005) note that the exchange rate reflects a country's fundamental economic conditions because it is affected by other fundamental variables, such as the money supply, output, the inflation rate, and the interest rate. Sarno and Schmeling (2014) reaffirm that the exchange rate is a strong and significant predictor of future macroeconomic fundamentals.

Likewise, Arifin and Syahruddin (2011) find evidence that fluctuations in exchange rates, defined as the value of a local currency in United States dollars, substantially impact stock market volatility in ASEAN-5 countries. This finding is confirmed by Jebran and Iqbal (2016), who observe asymmetric volatility between the stock and foreign exchange markets in Pakistan, China, Hong Kong, and Sri Lanka. Based on the former study, we assume that the stock market fundamental equation is as follows:

$$
R_{t}=a_{1 t}+a_{2} E R_{t}+\varepsilon_{t}
$$

where $R_{t}$ is the stock index return and $E R$ represents the change in each country's exchange rate relative to the United States dollar. For the United States, we use the United States Dollar Index.

We use the ordinary least squares (OLS) method and then test the stability of the parameters. The stability test is an essential step in determining whether structural changes exist using F-statistics (Chow, 1960). The stability test takes the form of a breakpoint test and recursive estimation (i.e., a one-step-ahead forecast test). This study uses the multiple breakpoint test, which is a refinement of the Chow breakpoint test model, to identify some possible breaks $(l)$. The general form of the equation is as follows:

$$
F(\hat{\delta})=\frac{1}{T}\left(\frac{T-(l+1) q-p}{k q}\right)(R \hat{\delta})^{\prime}\left(R \hat{V}(\hat{\delta}) R^{\prime}\right)^{-1} R \hat{\delta}
$$

where $\hat{\delta}$ is the optimal $l$-break estimate of $\delta$ and $(R \hat{\delta})^{\prime}=\left(\delta_{0}^{\prime}-\delta_{1}^{\prime}, \cdots, \delta_{l}^{\prime}-\delta_{l+1}{ }^{\prime}\right) . \hat{V}(\hat{\delta})$ is an estimate of the variance-covariance matrix of $\hat{\delta}$; it may be robust to serial correlation and heteroskedasticity, and its form depends on the assumptions regarding the distribution of the data and the errors across segments (Bai \& Perron, 2003). The number of breaks can be 
selected by considering an information criterion, such as the Bayesian information criterion or the modified Schwarz criterion (i.e., the Liu-Wu-Zidek (LWZ) criterion).

The one-step-ahead forecast test produces a plot of residuals and standard errors over the observation period with a P-value of $\leq 15 \%$. This plot describes the structural changes during the observation period.

\section{B. TGARCH model}

As stated before, stock return data mostly exhibit high and time-varying volatility, which usually leads to heteroskedasticity problems. Thus, this study uses the TGARCH model, an extension of the generalized autoregressive conditional heteroskedasticity (GARCH) model. We use a GARCH model to overcome the heteroskedasticity that arises from highly volatile data. Moreover, we use the TGARCH model to allow for different effects of good and bad news on volatility. The model used in this study is as follows:

$$
\begin{aligned}
& R=\mu_{i}+\varepsilon \\
& \sigma^{2}=\delta+\alpha_{i} \varepsilon_{i, t-1}^{2}+\theta_{i}\left(\varepsilon_{i, t-1}^{2} x d_{t-1}\right)+\beta_{i} \sigma_{i, t-1}^{2}+\gamma_{i} d_{j t}+\pi_{i} d_{j t} I_{k j=i},
\end{aligned}
$$

where $j$ is COVID-19 in the $k$ countries affected by COVID-19. Equation (4) is the conditional mean equation for stock index returns, and equation (5) is the variance equation, which models the volatility. We use the parameter $\alpha$ in equation (5) to investigate the autoregressive conditional heteroskedasticity (ARCH) effect, that is, whether a shock in the previous period affects stock return volatility. Moreover, we use the parameter $\beta$ to check whether stock return volatility is affected by volatility in the previous period (i.e., the GARCH effect). The TGARCH effect is reflected by the parameter $\theta$, which indicates whether positive and negative shocks impact stock return volatility differently.

To address this study's objective, that is, testing whether COVID-19 affects stock return volatility, we use the dummy variables $d_{j t}$ and $d_{j t} I_{k j=i}$. The dummy variable $d_{j t}$ takes a value of one when COVID-19 is present and a value of zero when it is absent. $I_{k j=i}$ is also a dummy variable and takes a value of one if COVID-19 is present in the country with stock index $i$. Thus, $d_{j t} I_{k j=i}$ accounts for the possibility that COVID-19 may have a greater impact on the given country. If stock index $i$ never experiences COVID-19 during the observed period, the variable $d_{j t} I_{k j=i}$ drops out of the equation. The total average effect of COVID-19 in the country with stock index $i$ is $\gamma_{i}+\pi_{i}$. 
28 Journal of Economic Integration Vol. 36, No. 1

\section{Analysis}

\section{A. Descriptive analysis}

Before carrying out the empirical analysis, we conduct a descriptive analysis of the COVID-19 period, defined as December 31, 2019, to June 30, 2020. Figure 3 shows that volatility is high in most countries, with high volatility primarily occurring in March 2020.

Figure 3. Stock return volatility in observed countries

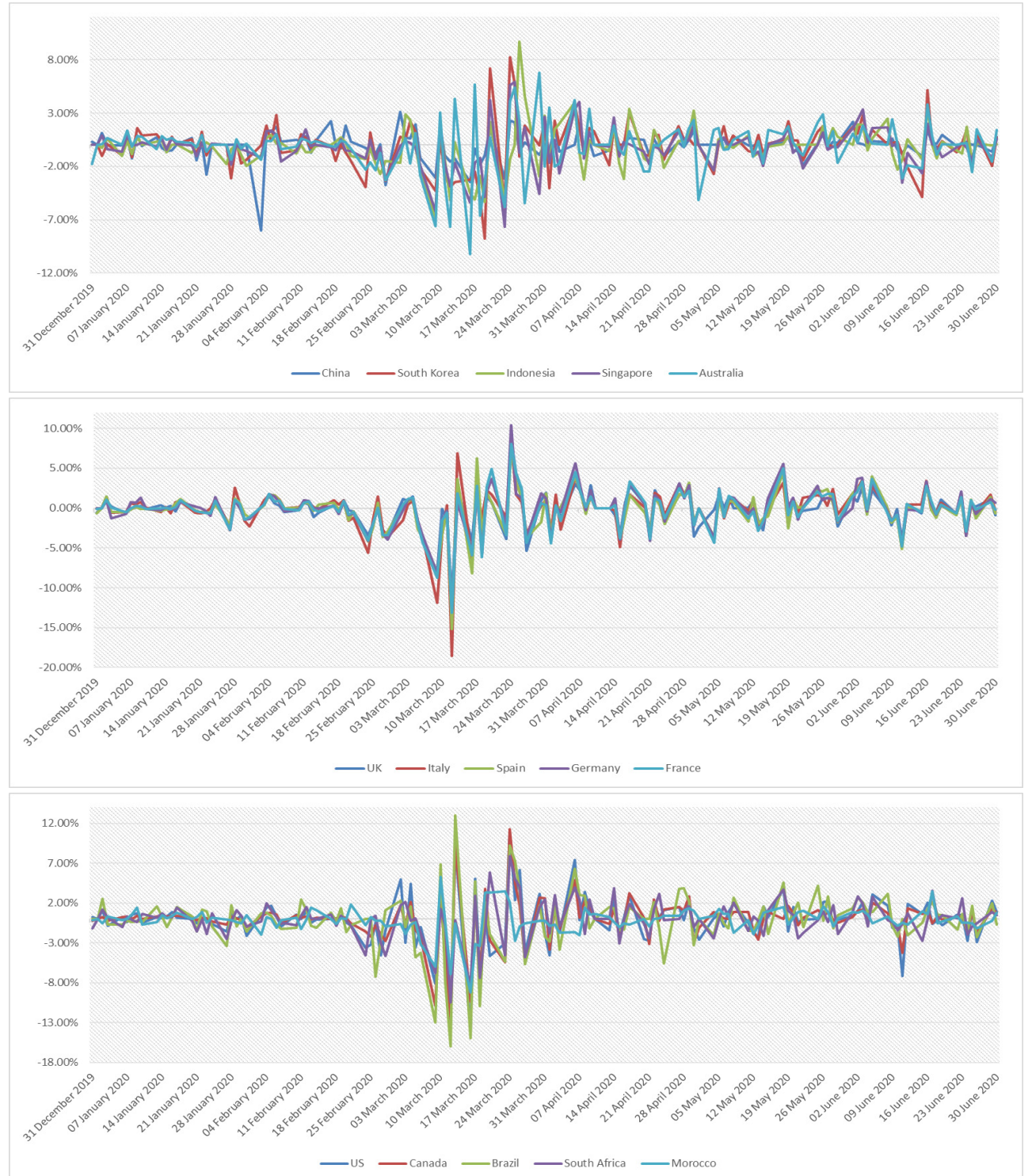

(Source) Authors' calculation using Bloomberg Terminal 2020 data 
The returns in each of the countries affected by COVID-19 reach their highest and lowest points in March 2020. Moreover, this high volatility occurs over a wide range of returns within a short period. For example, on March 12, 2020, the stock exchange in Brazil experienced a decline in returns of $15.99 \%$, but the returns increased by $13.02 \%$ on the following day. A similar brief return movement also occurred in Singapore. On March 23, 2020, the stock index fell to its lowest position with a return of $-7.64 \%$, but it subsequently rose with a return of $5.89 \%$ two days later. In Indonesia, the lowest return was $-6.81 \%$ on March 9, 2020, but the return increased to $9.70 \%$ over the next two weeks. Figure 4 shows the lowest and highest returns in each country affected by COVID-19.

Figure 4. Lowest and highest returns in observed countries

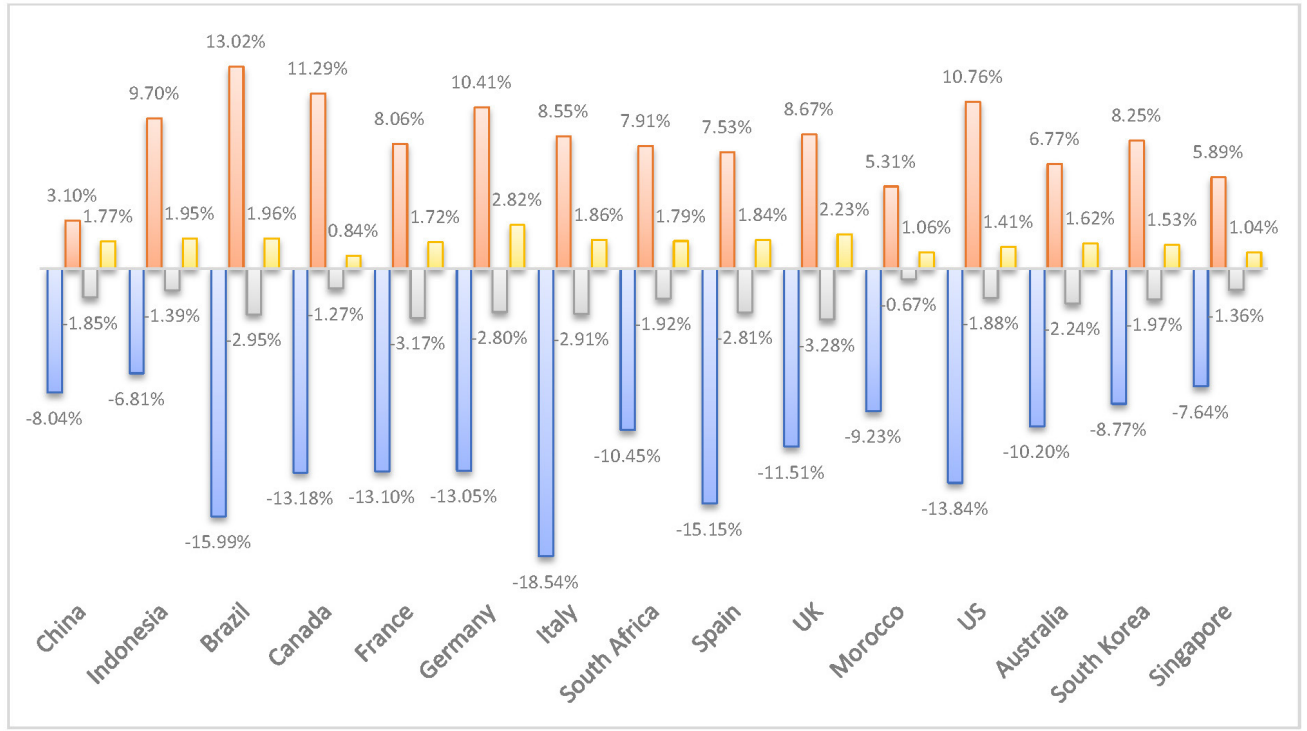

(Source) Authors' calculation using Bloomberg Terminal 2020 data

The range of global stock market returns was very high during the COVID-19 period, especially in March 2020, as returns ranged from $-18.54 \%$ to $13.02 \%$. The range of global stock market returns tended to be lower prior to the pandemic, ranging from $-3.64 \%$ to $2.82 \%$. When we exclude March 2020 from the sample, the volatility of global stock market returns ranges from $-8.04 \%$ to $7.45 \%$. This return range is still greater than that before the emergence of COVID-19. Based on the descriptive analysis, we show that the returns in the observed countries exhibit high volatility, reflected in their rapid changes across periods. We also observe that stock returns exhibit time-varying volatility.

Next, we conduct a descriptive analysis using data on COVID-19 cases. The number of cases in each country has been increasing as of June 30, 2020, as Figure 5 shows. Figure 5 also shows that the number of cases in China has reached its peak, and the number of 
COVID-19 cases in China is currently not significantly increasing. We observe a similar pattern for South Korea, as the flattening curve is an indication that a country is reducing its number of cases. In addition to China and South Korea, some other countries in this study are also experiencing flattening curves. These countries are Singapore, Australia, Canada, the United Kingdom, Italy, Spain, Germany, and France. However, other countries' case numbers, including those of Indonesia, the United States, Brazil, South Africa, and Morocco, are still exhibiting exponential growth patterns, as Figure 5 shows.

Figure 5. Number of COVID-19 cases in observed countries

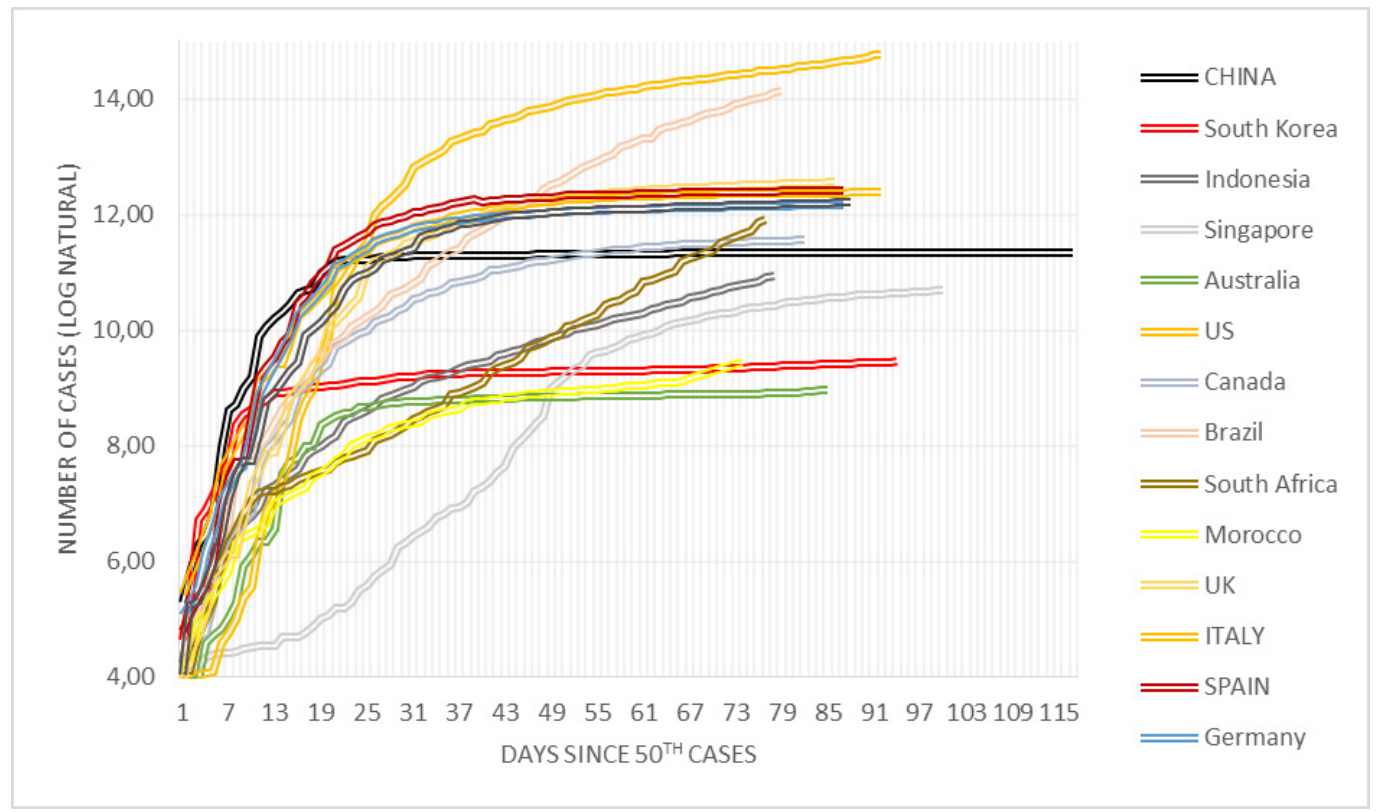

(Source) Author's calculation using Bloomberg Terminal 2020 data

Moreover, European countries have experienced the highest death rates. As shown in Table 2, the United Kingdom has the highest COVID-19 death rate of $15.36 \%$, followed by France, with a death rate of $14.77 \%$; Italy, with a death rate of $14.45 \%$; and Spain, with a death rate of $11.38 \%$. Among the Asian countries, Indonesia has the highest death rate, and Singapore has the lowest death rate. Furthermore, even though the United States is the country with the most cases as of June 30,2020, its death rate is below the average for the observed countries 1 ).

1) The average death rate is $6.37 \%$. 
Table 2. Numbers of COVID-19 Cases and Deaths

\begin{tabular}{|c|c|c|c|c|}
\hline Countries & First Cases & \#Cases & \#Death & Death Rate (\%) \\
\hline United Kingdom & 31-Jan-20 & 285,216 & 43,815 & 15.36 \\
\hline France & 24-Jan-20 & 202,063 & 29,846 & 14.77 \\
\hline Italy & 31-Jan-20 & 240,578 & 34,767 & 14.45 \\
\hline Spain & 03-Feb-20 & 249,271 & 28,355 & 11.38 \\
\hline Canada & 27-Jan-20 & 106,097 & 8,650 & 8.15 \\
\hline China & 31-Dec-19 & 84,785 & 4,641 & 5.47 \\
\hline Indonesia & 02-Mar-20 & 56,385 & 2,876 & 5.10 \\
\hline United States & 21-Jan-20 & $2,636,414$ & 127,432 & 4.83 \\
\hline Germany & 27-Jan-20 & 195,418 & 8,990 & 4.60 \\
\hline Brazil & $26-$ Feb-20 & $1,402,041$ & 59,594 & 4.25 \\
\hline South Korea & 21-Jan-20 & 12,850 & 282 & 2.19 \\
\hline Morocco & 02-Mar-20 & 12,533 & 228 & 1.82 \\
\hline South Africa & 05-Mar-20 & 151,209 & 2,657 & 1.76 \\
\hline Australia & 27-Jan-20 & 7,920 & 104 & 1.31 \\
\hline Singapore & 23-Jan-20 & 43,907 & 26 & 0.06 \\
\hline
\end{tabular}

(Source) Authors' calculations using Bloomberg Terminal 2020 data and the R "coronavirus" package.

\section{B. Empirical analysis}

\section{Fundamental Equation}

As with any other time-series data, we conduct a unit root test before estimating the fundamental equation using OLS. We use two unit root tests: the augmented Dickey-Fuller (ADF) test (Dickey \& Fuller, 1979) and the Phillips-Perron (PP) test (Phillips \& Perron, 1988). The unit root tests show that all of the variables in our analysis are stationary and have the same degree of integration at the difference level (0). We then estimate the OLS regression.

The OLS estimation results shown in Table 3 indicate that exchange rates significantly impact stock index returns in most of the observed countries. However, in several countries, such as Morocco, Italy, Spain, Germany, and the United States, the exchange rate's impact on stock index returns is insignificant. Table 3 shows that exchange rates and stock index returns are negatively related in China, the United Kingdom, Canada, South Korea, Brazil, Australia, Indonesia, South Africa, and Singapore. Thus, an exchange rate appreciation forces stock index returns to increase in these countries.

We use the OLS estimation results as a basis for estimating the breakpoint test to identify periods when abnormal changes occur. Table 4 shows the estimation results of breakpoint tests based on the Schwarz and LWZ criteria. We observe differences in the break dates across the observed countries. In some countries, the break dates are before the first COVID-19 case or before December 31, 2019. We observe such a result for China, the first country to experience 
Table 3. OLS Estimation

\begin{tabular}{cccccc}
\hline \multirow{2}{*}{ Negara } & Dependent & \multicolumn{2}{c}{ Constant } & \multicolumn{2}{c}{ Independent (ER) } \\
\cline { 3 - 5 } & & Coeff. & P-value & Coeff. & P-value \\
\hline United States & USA_return & 0.00025 & 0.7912 & 0.18758 & 0.4593 \\
Italy & Italy_Return & 0.00014 & 0.8827 & 0.13727 & 0.5503 \\
Spain & Spain_Return & -0.0004 & 0.6059 & 0.07831 & 0.7069 \\
Germany & Germany_Return & 0.00039 & 0.6400 & -0.0038 & 0.9857 \\
China & China_Return & 0.00051 & 0.3809 & -0.7374 & $0.0002^{*}$ \\
France & France_Return & 0.00011 & 0.8942 & -0.023 & 0.9115 \\
United Kingdom & UK_Return & -0.0002 & 0.7822 & -0.2526 & $0.0331^{*}$ \\
Canada & Canada_Return & 0.00019 & 0.8058 & -1.7238 & $0.0000^{*}$ \\
South Korea & South_Korea_Return & 0.00046 & 0.3709 & -1.8548 & $0.0000^{*}$ \\
Brazil & Brazil_Return & 0.00112 & 0.2845 & -1.0458 & $0.0000^{*}$ \\
Australia & Australia_Return & 0.00014 & 0.8478 & -0.5779 & $0.0000^{*}$ \\
Indonesia & Indonesia_Return & -0.0006 & 0.2506 & -1.3153 & $0.0000^{*}$ \\
South Africa & South_Africa_Return & 0.00045 & 0.5554 & -0.5431 & $0.0000^{*}$ \\
Singapore & Singapore_Return & -0.0003 & 0.5564 & -1.8400 & $0.0000^{*}$ \\
Morocco & Morocco_Return & -0.0003 & 0.1887 & 0.5806 & 0.2847 \\
\hline
\end{tabular}

(Source) Authors' calculations. *Significant at the $5 \%$ level

COVID-19, as the break date on its stock index is estimated to be April 5, 2019.

Break dates prior to the first case of COVID-19 are also observed for the United States, Italy, Spain, Germany, France, the United Kingdom, Singapore, Canada, Brazil, and South Africa, as Table 4 shows. However, these countries also have break dates after the first case of COVID-19 or after December 31, 2019. The existence of break dates before the COVID-19 pandemic may be explained by the fundamental model used to estimate breakpoints. In this model, exchange rates affect stock return volatility. Given that the exchange rate reflects a country's fundamental condition and is affected by fundamental variables, including the money supply, output, the inflation rate, the interest rate, and capital flows, break dates before COVID-19 may be driven by these fundamental variables.

Other countries, such as South Korea, Australia, Indonesia, and Morocco, have break dates after December 31, 2019. Moreover, all observed countries except China have break dates after December 31, 2019, and these break dates range from January 3, 2020, to March 30, 2020. Australia and South Africa have break dates in January 2020, Morocco has a break date in February 2020. Most of the observed countries, such as Singapore, Italy, the United Kingdom, Canada, the United States, Spain, Germany, France, and South Africa, have break dates in March 2020. Indonesia and Brazil are the countries with break dates in April 2020. 
Table 4. Breakpoint Test Estimations

\begin{tabular}{|c|c|c|c|c|c|c|}
\hline \multirow[b]{2}{*}{ Countries } & \multirow[b]{2}{*}{ First Cases } & \multicolumn{2}{|c|}{ Variable } & \multicolumn{3}{|c|}{ Breakpoint Test } \\
\hline & & Dependent & Independent & $\begin{array}{c}\text { Estimated } \\
\text { Break Dates }\end{array}$ & $\begin{array}{l}\text { Schwarz } \\
\text { Criterion }\end{array}$ & $\begin{array}{c}\text { LWZ } \\
\text { Criterion }\end{array}$ \\
\hline China & 31-Dec-19 & China_Return & China_ER & 05-Apr-19 & -8.893638 & -8.853896 \\
\hline \multirow[t]{3}{*}{ USA } & 21-Jan-20 & USA_Return & USA_ER & 01-Aug-19 & -7.984122 & -7.874426 \\
\hline & & & & 27-Dec-19 & & \\
\hline & & & & 18-Mar-20 & & \\
\hline \multirow[t]{2}{*}{ South Korea } & 21-Jan-20 & South_Korea_Return & South_Korea_ER & 06-Jan-20 & -9.213377 & -9.11801 \\
\hline & & & & 27-Mar-20 & & \\
\hline \multirow[t]{2}{*}{ Singapore } & 23-Jan-20 & Singapore_Return & Singapore_ER & 16-Dec-19 & -9.040129 & -8.945654 \\
\hline & & & & 09-Mar-20 & & \\
\hline \multirow[t]{3}{*}{ France } & 24-Jan-20 & France_Return & France_ER & 16-Jul-19 & -8.23696 & -8.165837 \\
\hline & & & & 30-Dec-19 & & \\
\hline & & & & 20-Mar-20 & & \\
\hline \multirow[t]{2}{*}{ Germany } & 27-Jan-20 & Germany_Return & Germany_ER & 30-Dec-19 & -8.194028 & -8.132395 \\
\hline & & & & 20-Mar-20 & & \\
\hline \multirow[t]{3}{*}{ Canada } & 27-Jan-20 & Canada_Return & Canada_ER & 19-Aug-19 & -8.606047 & -8.446921 \\
\hline & & & & 26-Dec-19 & & \\
\hline & & & & 17-Mar-20 & & \\
\hline \multirow[t]{2}{*}{ Australia } & 27-Jan-20 & Australia_Return & Australia_ER & 03-Jan-20 & -8.43501 & -8.381428 \\
\hline & & & & 25-Mar-20 & & \\
\hline \multirow[t]{3}{*}{ Italy } & 31-Jan-20 & Italy_Return & Italy_ER & 22-Jul-19 & -8.020174 & -7.952805 \\
\hline & & & & 19-Dec-19 & & \\
\hline & & & & 10-Mar-20 & & \\
\hline \multirow[t]{2}{*}{ United Kingdom } & 31-Jan-20 & UK_Return & UK_ER & 20-Dec-19 & -8.479416 & -8.398173 \\
\hline & & & & 11-Mar-20 & & \\
\hline \multirow[t]{3}{*}{ Spain } & 03-Feb-20 & Spain_Return & Spain_ER & 01-May-19 & -8.228481 & -8.150132 \\
\hline & & & & 30-Dec-19 & & \\
\hline & & & & 24-Mar-20 & & \\
\hline \multirow[t]{3}{*}{ Brazil } & $26-F e b-20$ & Brazil_Return & Brazil_ER & 28-Aug-19 & -7.824469 & -7.70734 \\
\hline & & & & 16-Jan-20 & & \\
\hline & & & & $08-A p r-20$ & & \\
\hline Morocco & 02-Mar-20 & Morocco_Return & Morocco_ER & $24-F e b-20$ & -9.100335 & -9.060594 \\
\hline Indonesia & 02-Mar-20 & Indonesia_Return & Indonesia_ER & 07-Apr-20 & -9.038642 & -8.9989 \\
\hline \multirow[t]{3}{*}{ South Africa } & 05-Mar-20 & South_Africa_Return & South_Africa_ER & 15-Oct-19 & -8.498606 & -8.343623 \\
\hline & & & & 08-Jan-20 & & \\
\hline & & & & 30-Mar-20 & & \\
\hline
\end{tabular}

(Source) Authors' calculations. 
Interestingly, most of the observed countries have break dates after their first domestic COVID-19 cases; these countries include the United States, Italy, Spain, Germany, France, the United Kingdom, Canada, Brazil, Indonesia, and Singapore. However, several countries' break dates are prior to their first domestic COVID-19 cases. These countries are China, South Korea, Australia, South Africa, and Morocco.

The one-step-ahead forecast produces a plot of the recursive residuals and standard errors and the sample points with P-values less than or equal to $15 \%$, as Figure 6 shows. The upper portion of the plot, measured on the right vertical axis, displays the recursive residuals and standard errors. Residuals outside the standard error bands suggest that the equation's parameters are unstable.

Figure 6. One-step-ahead forecasts
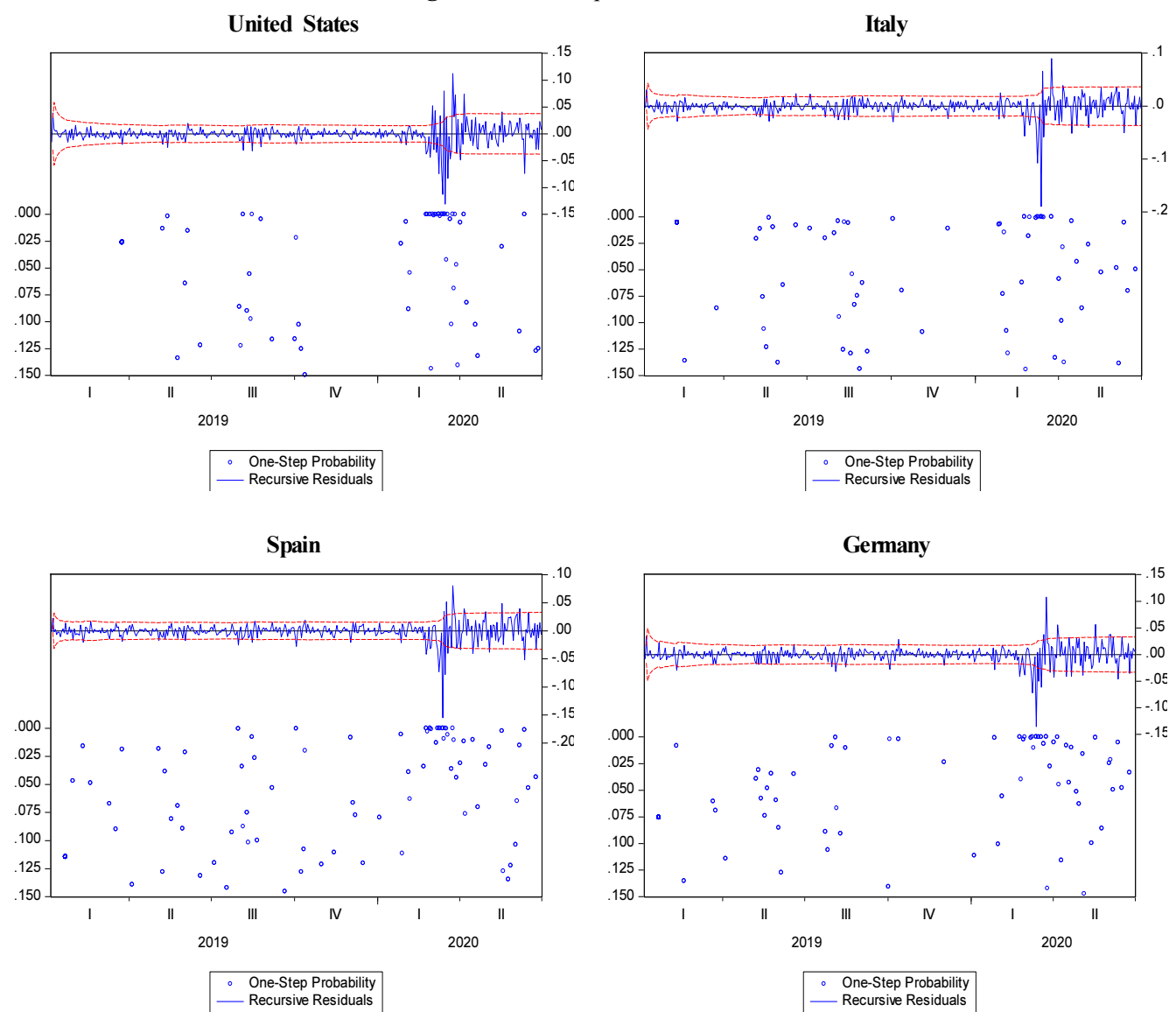
Figure 6. Continued
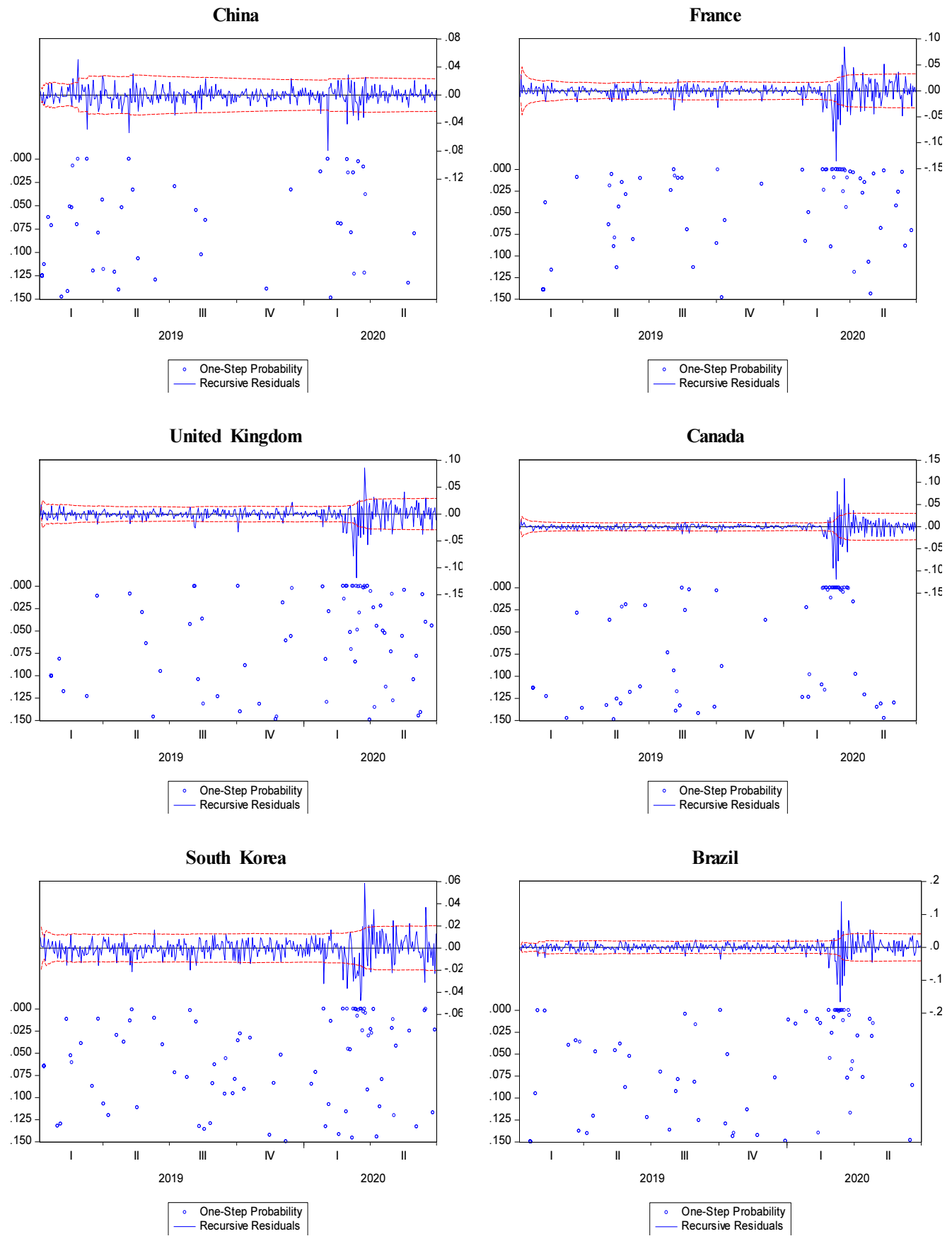

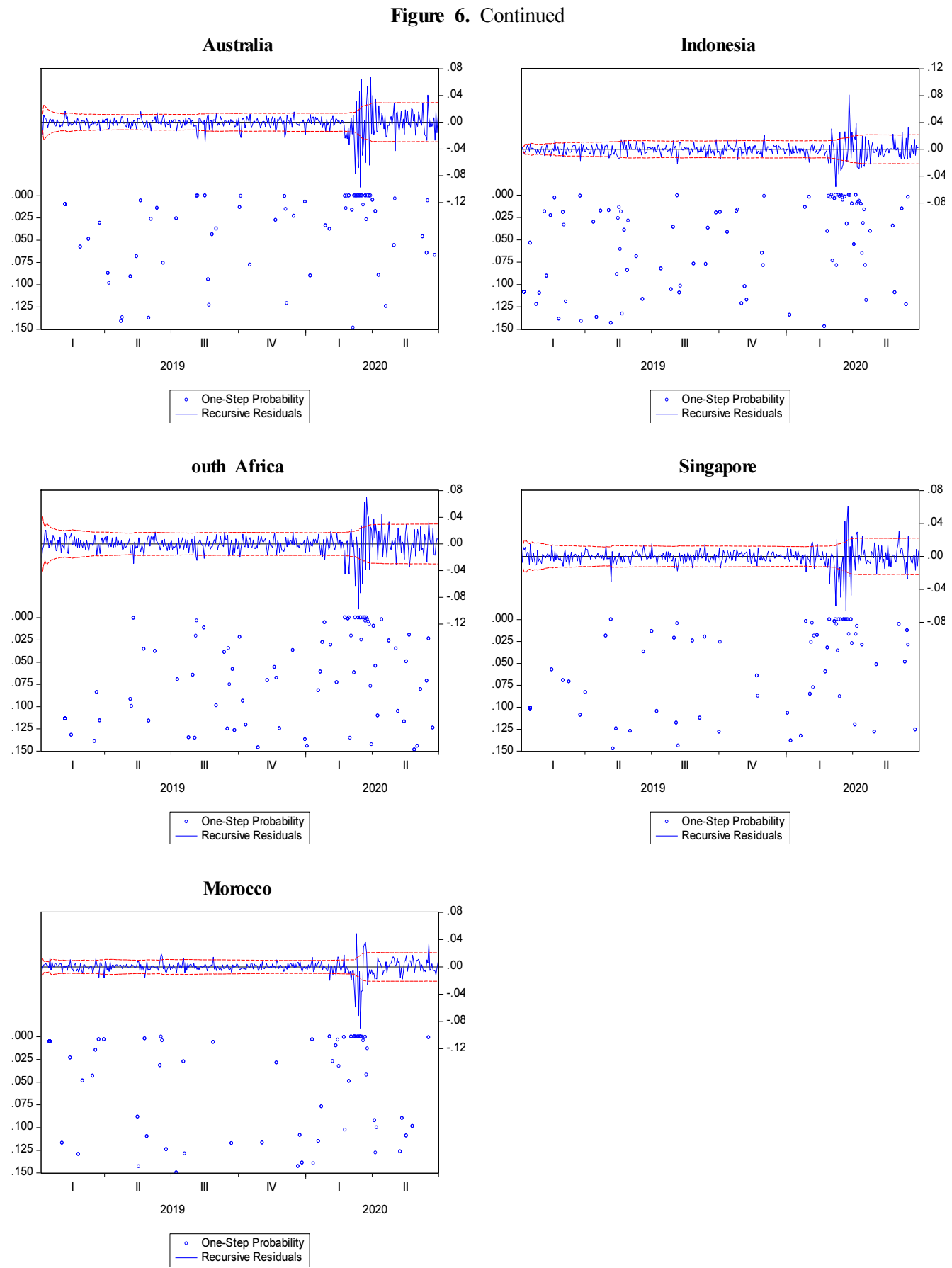

(Source) Author's calculations.

The lower part of the plot, measured on the left vertical axis, shows the P-values for the sample points for which the hypothesis of parameter constancy is rejected at the $5 \%, 10 \%$, or $15 \%$ 
significance level ("EViews Help: Stability Diagnostics," n.d.). The points with P-values below the usual significance level (i.e., 0.05) correspond to those points whose recursive residuals are outside the two standard error bounds. In this case, we find evidence of instability in the observed period for all observed countries. In each country, the one-step probability is less than 0.05 . This finding supports the results of the breakpoint tests, which indicate structural changes during the observed period.

\section{TGARCH Model}

Before performing regressions using the TGARCH method, we perform a normality test to determine whether the residuals are normally distributed by examining the Jarque-Berra P-values, skewness, and kurtosis of their distribution. The existence of a non-normal distribution indicates volatility clustering for the returns. Table 5 shows the results of the residual normality test for the returns.

As Table 5 shows, all of the variables have skewness values that are different from zero, meaning that the distribution is left-skewed. In addition, the kurtosis values are greater than three, indicating a leptokurtic, or non-normal, distribution. Using an alpha value of 0.05 , we can reject the null hypothesis that the residuals follow a normal distribution. Thus, we can conclude that the residual distribution of the returns is not normal.

Table 5. Normality Test Results

\begin{tabular}{lccccc}
\hline Normality Test & China & South Korea & Indonesia & Singapore & Australia \\
\hline Skewness & -1.032145 & -0.178659 & 0.269611 & -0.831947 & -1.465815 \\
Kurtosis & 11.38932 & 12.60880 & 15.40914 & 13.35750 & 14.52893 \\
P-value & 0.0000 & 0.0000 & 0.0000 & 0.0000 & 0.0000 \\
\hline Normality Test & $\mathrm{US}$ & Canada & Brazil & South Africa & Morocco \\
\hline Skewness & -1.022245 & -1.787362 & -1.701166 & -1.166497 & -2.516095 \\
Kurtosis & 18.24626 & 29.09907 & 19.24047 & 13.46653 & 27.53884 \\
P-value & 0.0000 & 0.0000 & 0.0000 & 0.0000 & 0.0000 \\
\hline Normality Test & $\mathrm{UK}$ & Italy & Spain & Germany & France \\
\hline Skewness & -1.506401 & -3.389028 & -2.377722 & -1.174983 & -1.805006 \\
Kurtosis & 18.28206 & 36.35001 & 25.07150 & 18.60026 & 17.91261 \\
P-value & 0.0000 & 0.0000 & 0.0000 & 0.0000 & 0.0000 \\
\hline
\end{tabular}

(Source) Authors' calculation.

We also perform an ARCH effect test to evaluate the heteroskedastic properties of the return variables. The null hypothesis is that there is no $\mathrm{ARCH}$ effect because the variance residuals are constant. As Table 6 shows, we find strong evidence that the variance residuals of the variables exhibit ARCH effects. Based on this result, we use the TGARCH model to estimate the impact 
of COVID-19 on global stock market volatility.

Table 6. ARCH Effect Test Results

\begin{tabular}{lccccc}
\hline Heteroskedasticity Test: ARCH & China & South Korea & Indonesia & Singapore & Australia \\
\hline F-statistic & 15.91620 & 301.78370 & 21.25793 & 122.76670 & 92.59830 \\
Obs*R-squared & 15.99170 & 170.62690 & 20.25763 & 93.73952 & 75.14246 \\
P-value & 0.0001 & 0.0000 & 0.0000 & 0.0000 & 0.0000 \\
\hline Heteroskedasticity Test: ARCH & US & Canada & Brazil & South Africa & Morocco \\
\hline F-statistic & 89.91991 & 85.36585 & 202.09910 & 8.86183 & 16.50397 \\
Obs*R-squared & 73.37791 & 70.33182 & 133.56850 & 8.70861 & 15.91220 \\
P-value & 0.0000 & 0.0000 & 0.0000 & 0.0032 & 0.0001 \\
\hline Heteroskedasticity Test: ARCH & UK & Italy & Spain & Germany & France \\
\hline F-statistic & 7.60239 & 6.46788 & 5.98992 & 14.54010 & 30.13078 \\
Obs*R-squared & 7.49473 & 6.39462 & 5.92926 & 14.60960 & 30.05271 \\
P-value & 0.0062 & 0.0114 & 0.0149 & 0.0000 & 0.0000 \\
\hline
\end{tabular}

(Source) Authors' calculations.

The previous breakpoint test found structural changes during the observed period. Thus, in this model, we define periods based on the estimated break dates to examine whether COVID-19 impacts stock return volatility in each country.

Table 7 shows the estimation results using the TGARCH method in Asia and Australia. As Table 7 shows, COVID-19 significantly impacts stock return volatility. However, its effect differs in different countries. In China and Singapore, the first global occurrence of COVID-19 affects stock return volatility. Conversely, in South Korea, Indonesia, and Australia, COVID-19 only impacts stock return volatility after the first domestic case. Although we find evidence that COVID-19 impacts stock volatility, this impact is small, as the parameter estimates of $d_{j t}$ and $d_{j t} I_{k j=i}$ indicate.

The estimation results in Table 7 also provide evidence of ARCH and GARCH effects. The ARCH effect means that stock return volatility in a given country is affected by the previous period's shock. Additionally, the GARCH effect means that stock return volatility is affected by the previous period's volatility. We also find TGARCH effects, meaning that positive and negative shocks have different impacts in the observed countries.

As Table 7 shows, negative shocks have greater impacts on stock return volatility than positive shocks do in all observed countries. Stock return volatility is more affected by negative shocks in Singapore than in the other Asian countries in our sample. In Singapore, the effect of a negative shock on stock return volatility is 0.406 points higher than that of a positive shock. Stock return volatility is less affected by negative shocks in Australia than in the other Asian countries. 
Table 7. TGARCH Estimation Results - 1

\begin{tabular}{lccccc}
\hline Mean Equation & China & South Korea & Indonesia & Singapore & Australia \\
\hline Constant & -0.000609 & 0.000444 & -0.000328 & $-1.47 \mathrm{E}-05$ & 0.0007 \\
& $(0.271)$ & $(0.0778)$ & $(0.2058)$ & $(0.9536)$ & $(0.0979)$ \\
\hline Variance Equation & China & South Korea & Indonesia & Singapore & Australia \\
\hline Constant & $1.15 \mathrm{E}-05$ & $8.26 \mathrm{E}-06$ & $1.32 \mathrm{E}-05$ & $3.56 \mathrm{E}-07$ & $5.25 \mathrm{E}-06$ \\
& $(0.0000)^{*}$ & $(0.0000)^{*}$ & $(0.0013)^{*}$ & $(0.1505)$ & $(0.0005)^{*}$ \\
ARCH Effect & -0.11842 & -0.135466 & -0.121836 & -0.240079 & $-6.91 \mathrm{E}-02$ \\
& $(0.0000)^{*}$ & $(0.0000)^{*}$ & $(0.0000)^{*}$ & $(0.0217)^{*}$ & $(0.0014)^{*}$ \\
TGARCH Effect & 0.28949 & 0.31227 & 0.317998 & 0.406852 & $2.11 \mathrm{E}-01$ \\
\multirow{2}{*}{ GARCH Effect } & $(0.0000)^{*}$ & $(0.0000)^{*}$ & $(0.0001)^{*}$ & $(0.0336)^{*}$ & $(0.0000)^{*}$ \\
& 0.885804 & 0.846509 & 0.688946 & 0.81234 & $8.46 \mathrm{E}-01$ \\
$d_{j t}$ & $(0.0000)^{*}$ & $(0.0000)^{*}$ & $(0.0000)^{*}$ & $(0.0000)^{*}$ & $(0.0000)^{*}$ \\
& $-3.38 \mathrm{E}-06$ & $3.78 \mathrm{E}-07$ & $2.37 \mathrm{E}-07$ & $8.54 \mathrm{E}-06$ & $-2.94 \mathrm{E}-07$ \\
$d_{j t} I_{k j=i}$ & $(0.0209)^{*}$ & $(0.9527)$ & $(0.9516)$ & $(0.0047)^{*}$ & $(0.9245)$ \\
& & $3.05 \mathrm{E}-05$ & 0.000433 & $1.95 \mathrm{E}-05$ & $2.97 \mathrm{E}-05$
\end{tabular}

(Source) Authors' calculations. *Significant at the 5\% level.

Table 8 shows the estimation results for countries in the Americas and Africa. These results show that COVID-19 also affects stock return volatility in these countries. In Canada and Morocco, the first emergence of COVID-19 worldwide affects stock return volatility. In contrast, COVID-19 only impacts stock return volatility in the United States, Brazil, and South Africa once it emerges domestically. As in the results for Asian countries, we find that the effect of COVID-19 on stock volatility is small, as the estimates of $d_{j t}$ and $d_{j t} I_{k j=i}$ indicate.

As the estimation results in Table 8 show, we find evidence of the ARCH effect only for Brazil, South Africa, and Morocco. In those countries, stock return volatility is affected by shocks in the previous period. We also find evidence that stock return volatility is affected by the previous period's volatility in the United States, Brazil, South Africa, and Morocco. Among our sample countries, South Africa's stock return volatility is the most affected by volatility in the previous period. Additionally, we observe the TGARCH effect for the United States, Brazil, and South Africa. This effect means that negative shocks have greater impacts on stock return volatility than positive shocks do. Stock return volatility is more affected by negative shocks in the United States than in the other American and African countries in our sample. Based on these results, the effect of a negative shock on stock return volatility is 0.485 points greater than that of a positive shock in the United States. Brazil's stock return volatility is less affected by negative shocks than those of other countries are. 
Table 8. TGARCH Estimation Results - 2

\begin{tabular}{lccccc}
\hline Mean Equation & United States & Canada & Brazil & South Africa & Morocco \\
\hline Constant & 0.000886 & 0.000826 & 0.000955 & -0.000729 & 0.000262 \\
& $(0.2775)$ & $(0.1679)$ & $(0.2159)$ & $(0.0607)$ & $(0.3583)$ \\
\hline Variance Equation & United States & Canada & Brazil & South Africa & Morocco \\
\hline Constant & $4.29 \mathrm{E}-05$ & 0.000284 & $1.21 \mathrm{E}-05$ & $8.28 \mathrm{E}-06$ & $5.24 \mathrm{E}-06$ \\
& $(0.3164)$ & $(0.0000)^{*}$ & $(0.0626)$ & $(0.0688)$ & $(0.0069)^{*}$ \\
ARCH Effect & -0.07844 & 0.46379 & -0.149661 & -0.232874 & 0.133955 \\
& $(0.2632)$ & $(0.6358)$ & $(0.0019)^{*}$ & $(0.0129)^{*}$ & $(0.0035)^{*}$ \\
TGARCH Effect & 0.485623 & 2.055316 & 0.181593 & 0.233318 & -0.013399 \\
GARCH Effect & $(0.0113)^{*}$ & $(0.0739)$ & $(0.0149)^{*}$ & $(0.0108)^{*}$ & $(0.8677)$ \\
& 0.750589 & 0.0672 & 0.878029 & 1.021045 & 0.619584 \\
$d_{j t}$ & $(0.0000)^{*}$ & $(0.7058)$ & $(0.0000)^{*}$ & $(0.0000)^{*}$ & $(0.0000)^{*}$ \\
& $-4.31 \mathrm{E}-05$ & 0.00028 & $1.37 \mathrm{E}-05$ & $2.58 \mathrm{E}-06$ & $1.03 \mathrm{E}-05$ \\
$d_{j t} I_{k j=i}$ & $(0.3166)$ & $(0.0000)^{*}$ & $(0.0574)$ & $(0.5633)$ & $(0.0244)^{*}$ \\
& $6.14 \mathrm{E}-05$ & 0.00000538 & 0.00086 & 0.000296 & $-2.14 \mathrm{E}-05$ \\
\hline
\end{tabular}

(Source) Authors' calculations. *Significant at the $5 \%$ level.

COVID-19 also affects stock volatility in European countries, as Table 9 shows. For Italy, Spain, Germany, and France, we find evidence that stock return volatility is positively affected by the first domestic appearance of COVID-19. Thus, when COVID-19 occurs in these countries, stock return volatility tends to increase. However, the effect of COVID-19 on stock return volatility is small, as the parameter estimates of $d_{j t}$ and $d_{j t} I_{k j=i}$ indicate. We find no evidence that COVID-19 affects stock index return volatility in the United Kingdom; this result differs from those for the other countries in our sample.

As the estimation results in Table 9 show, we find evidence of the ARCH effect only in Italy. However, we observe the GARCH and TGARCH effects for all European countries except the United Kingdom. Stock return volatility is more affected by negative shocks in Spain than in other European countries. The effect of a negative shock on stock return volatility is 0.887 points greater than that of a positive shock in Spain. Italy's stock return volatility is less affected by negative shocks than those of other countries are. 
Table 9. TGARCH Estimation Results - 3

\begin{tabular}{lccccc}
\hline Mean Equation & United Kingdom & Italy & Spain & Germany & France \\
\hline Constant & -0.000148 & -0.001084 & -0.001174 & $-7.67 \mathrm{E}-06$ & -0.0021 \\
& $(0.868)$ & $(0.375)$ & $(0.5355)$ & $(0.9949)$ & $(0.1632)$ \\
\hline Variance Equation & United Kingdom & Italy & Spain & Germany & France \\
\hline Constant & $7.24 \mathrm{E}-06$ & $9.65 \mathrm{E}-06$ & 0.000399 & 0.00053 & 0.000325 \\
& $(0.2944)$ & $(0.1022)$ & $(0.4742)$ & $(0.3802)$ & $(0.4722)$ \\
ARCH Effect & 0.269038 & -0.176168 & -0.252104 & -0.168124 & -0.146647 \\
TGARCH Effect & $(0.4107)$ & $(0.0008)^{*}$ & $(0.1556)$ & $(0.1177)$ & $(0.5063)$ \\
& 0.585206 & 0.422251 & 0.887625 & 0.718363 & 0.875517 \\
GARCH Effect & $(0.3175)$ & $(0.0000)^{*}$ & $(0.0197)^{*}$ & $(0.002)^{*}$ & $(0.0529)^{*}$ \\
& 0.463052 & 0.773952 & 0.560098 & 0.578272 & 0.536012 \\
$d_{j t}$ & $(0.1658)$ & $(0.0000)^{*}$ & $(0.0005)^{*}$ & $(0.0000)^{*}$ & $(0.0004)^{*}$ \\
$d_{j t} I_{k j=i}$ & $-2.91 \mathrm{E}-06$ & $1.58 \mathrm{E}-05$ & -0.000377 & -0.000522 & -0.000313 \\
& $(0.7677)$ & $(0.0806)$ & $(0.4966)$ & $(0.3874)$ & $(0.4861)$ \\
\hline
\end{tabular}

(Source) Authors' calculations. *Significant at the $5 \%$ level.

\section{Conclusion}

This study aimed to examine the impact of the COVID-19 pandemic on stock return volatility in several countries affected by the disease. The descriptive analysis of the return data showed that each country's stock returns exhibit high volatility during the COVID-19 pandemic, especially in March 2020. Moreover, we also found that the number of cases has peaked in most countries, including China, South Korea, Singapore, Australia, Canada, the United Kingdom, Italy, Spain, Germany, and France. Additionally, we observed that the curves of COVID-19 cases are flattening in these countries. However, in the other observed countries, that is, Indonesia, the United States, Brazil, South Africa, and Morocco, the number of cases is still increasing exponentially. Furthermore, as of June 30, 2020, the average death rate due to COVID-19 was $6.37 \%$.

Our analysis of the fundamental factors affecting stock returns found that changes in the exchange rate significantly impact stock returns in most of the countries in our sample, with the exceptions of Morocco, countries that use the euro (i.e., Italy, Spain, Germany, and France), and the United States. We found that in China, the United Kingdom, Canada, South Korea, Brazil, Australia, Indonesia, South Africa, and Singapore, the exchange rate negatively affects stock returns. Thus, an appreciation of the exchange rate forces stock index returns to increase in these countries. 
In addition, we conducted a breakpoint test to identify structural changes in the stock market during the observed period. The results show that structural changes occurred in each country over the observed period. In most countries, structural changes occurred before the first COVID-19 case. However, in these countries, we also observed break dates after either the first domestic case of COVID-19 or December 31, 2019.

For periods defined based on the estimated break dates, we examined whether COVID-19 has impacted on stock return volatility in the observed countries. We conducted TGARCH estimations and found evidence that the emergence of COVID-19 has affected stock return volatility in all observed countries except the United Kingdom. In China, Singapore, Canada, and Morocco, the first global outbreak of COVID-19 affected stock return volatility. In contrast, for South Korea, Indonesia, Australia, United States, Brazil, South Africa, Italy, Spain, Germany, and France, we found evidence that volatility returns are positively affected by the domestic emergence of COVID-19. Thus, when COVID-19 first occurred in these countries, stock return volatility tended to increase. However, the effect of COVID-19 on stock volatility is small in all of the observed countries.

Based on our findings, we encourage researchers to conduct more in-depth studies of the factors that affect stock return volatility, especially during pandemics, because other factors besides the occurrence of COVID-19 may affect stock return volatility. For example, factors such as the number of cases, the number of deaths, the death rate, and the government's response to the COVID-19 may impact stock return volatility.

Additionally, as a recommendation to policymakers, we suggest that governments should not just focus on the health sector but should also maintain the exchange rate's stability because both factors are closely related to stock return volatility. The health sector affects households' behavior and demand for products and corporate cash flows. Although the exchange rate may change corporation's cost structures, it may also affect product competitiveness at a global scale. Furthermore, cash flows and product competitiveness can allow investors to determine the fair value of a corporation and generate sentiment, affecting stock prices.

\section{References}

Al-Tamimi, H. A. H., Alwan, A. A., \& Rahman, A. A. A. (2011). Factors affecting stock prices in the UAE financial markets. Journal of Transnational Management, 16(1), 3-19. doi:10.1080/15475778.201 1.549441

Albulescu, C. (2020). Coronavirus and financial volatility: 40 days of fasting and fear. SSRN Electronic Journal. doi:10.2139/ssrn.3550630

Arifin, J., \& Syahruddin, N. (2011). Volatility spillovers between equity and currency markets in ASEAN-5 
countries during crises. Proceedings of 13th International Conference on Finance and Banking: Lesson s Learned from the Financial Crisis, 12. Retrieved from http://www.opf.slu.cz/kfi/icfb/proc2011/procee dings.html

Bae, K. H., \& Andrew Karolyi, G. (1994). Good news, bad news and international spillovers of stock return volatility between Japan and the U.S. Pacific-Basin Finance Journal, 2(4), 405-438. doi:10.1016/ 0927-538X(94)90003-5

Bai, J., \& Perron, P. (2003). Computation and analysis of multiple structural change models. Journal of Applied Econometrics, 18(1), 1-22. doi:10.1002/jae.659

Baker, S. R., Bloom, N., Davis, S. J., Kost, K., Sammon, M., \& Viratyosin, T. (2020). The unprecedented stock market reaction to COVID-19. The Review of Asset Pricing Studies, 10(4), 742-758. doi:10.1093/rapstu/raaa008

Bodie, Z., Kane, A., \& Marcus, A. J. (2013). Essentials of investments (9th ed.). New York: McGraw-Hill.

Chan, W. C. (2003). Stock price reaction to news and no-news: Drift and reversal after headlines. Journal of Financial Economics, 70(2), 223-260. doi:10.1016/S0304-405X(03)00146-6

Chen, C.-D., Chen, C.-C., Tang, W.-W., \& Huang, B.-Y. (2009). The positive and negative impacts of the Sars Outbreak: A case of the Taiwan industries. The Journal of Developing Areas, 43(1), 281-293. doi:10.1353/jda.0.0041

Chen, M. H., Jang, S. C. (Shawn), \& Kim, W. G. (2007). The impact of the SARS outbreak on Taiwanese hotel stock performance: An event-study approach. International Journal of Hospitality Management, 26(1), 200-212. doi:10.1016/j.ijhm.2005.11.004

Chow, G. C. (1960). Tests of equality between sets of coefficients in two linear regressions. Econometrica, 28(3), 591. doi:10.2307/1910133

Dickey, D. A., \& Fuller, W. A. (1979). Distribution of the estimators for autoregressive time series with a unit root. Journal of the American Statistical Association, 74(366), 427. doi:10.2307/2286348

Dornbusch, R., Park, Y. C., \& Claessens, S. (2000). Contagion: understanding how it spreads. The World Bank Research Observer, 15(2), 177-197.

Engel, C., \& West, K. D. (2005). Exchange rates and fundamentals. Journal of Political Economy, 113(3), 485-517. doi:10.1086/429137

EViews Help: Stability Diagnostics. (n.d.). Retrieved August 28, 2020, from http://www.eviews.com/help/h elpintro.html\#page/content\%2Ftesting-Stability_Diagnostics.html\%23ww183815

Hill, R. C., Griffiths, W. E., \& Lim, G. C. (2011). Principles of econometrics (4th ed.). Hoboken, New Jersey: John Wiley \& Sons, Inc.

Isidore, R., \& Christie, P. (2018). A behavioral finance perspective of the stock market anomalies. International Journal of Research in Management, Economics and Commerce, 8(4), 5-9.

Jebran, K., \& Iqbal, A. (2016). Dynamics of volatility spillover between stock market and foreign exchange market: evidence from Asian countries. Financial Innovation, 2(1). doi:10.1186/s40854-016-0021-1

Liu, H., Manzoor, A., Wang, C., Zhang, L., \& Manzoor, Z. (2020). The COVID-19 outbreak and affected countries stock markets response. International Journal of Environmental Research and Public Health, 17(8). doi:10.3390/ijerph17082800

Nippani, S., \& Washer, K. M. (2004). SARS: A non-event for affected countries' stock markets? Applied 
44 Journal of Economic Integration Vol. 36, No. 1

Financial Economics, 14(15), 1105-1110. doi:10.1080/0960310042000310579

Phillips, P. C. B., \& Perron, P. (1988). Testing for a unit root in time series regression. Biometrika, 75(2), 335-346. doi:10.1093/biomet/75.2.335

Ramiah, V. (2013). Effects of the boxing day tsunami on the world capital markets. Review of Quantitative Finance and Accounting, 40(2), 383-401. doi:10.1007/s11156-012-0286-Z

Sahel, B., \& Vesala, J. (2001). Financial stability analysis using aggregated data. Marrying the Macro-and Micro-Prudential Dimensions of Financial Stability, 1, 160-185.

Sarno, L., \& Schmeling, M. (2014). Which fundamentals drive exchange rates? A cross-sectional perspective. Journal of Money, Credit and Banking, 46(2-3), 267-292. doi:10.1111/jmcb.12106

Shiller, R. J. (2003). From efficient markets theory to behavioral finance. Journal of Economic Perspectives, 17(1), 83-104. doi:10.1257/089533003321164967

World Health Organization. (2020). Coronavirus disease (COVID-19): situation report, 162. Retrieved from https://apps.who.int/iris/handle/10665/332970

Zeren, F., \& Hizarci, A. (2020). The impact of Covid-19 coronavirus on stock markets: Evidence from selected countries. Muhasebe ve Finans İncelemeleri Dergisi, 3(1), 78-84. doi:10.32951/mufider.706159 
Appendix 1. Unit Root Test

\begin{tabular}{|c|c|c|c|c|c|}
\hline \multirow{2}{*}{ Countries } & \multirow{2}{*}{ Variable } & \multicolumn{2}{|c|}{ ADF Test } & \multicolumn{2}{|c|}{ PP Test } \\
\hline & & t-stat & P-value & Adj t-stat & P-value \\
\hline \multirow[t]{2}{*}{ USA } & USA_return & -6.4610 & $0.0000^{*}$ & -26.2003 & $0.0000^{*}$ \\
\hline & USA_ER & -17.2126 & $0.0000^{*}$ & -17.2629 & $0.0000^{*}$ \\
\hline \multirow[t]{2}{*}{ Italy } & Italy_Return & -8.9053 & $0.0000^{*}$ & -21.7126 & $0.0000^{*}$ \\
\hline & Italy_ER & -18.0743 & $0.0000^{*}$ & -18.1337 & $0.0000 *$ \\
\hline \multirow[t]{2}{*}{ Spain } & Spain_Return & -11.2448 & $0.0000 *$ & -21.5626 & $0.0000 *$ \\
\hline & Spain_ER & -18.0743 & $0.0000^{*}$ & -18.1337 & $0.0000^{*}$ \\
\hline \multirow[t]{2}{*}{ Germany } & Germany_Return & -12.0951 & $0.0000^{*}$ & -19.8406 & $0.0000^{*}$ \\
\hline & Germany_ER & -18.0743 & $0.0000^{*}$ & -18.1337 & $0.0000 *$ \\
\hline \multirow[t]{2}{*}{ China } & China_Return & -20.4378 & $0.0000^{*}$ & -20.4381 & $0.0000^{*}$ \\
\hline & China_ER & -21.5407 & $0.0000^{*}$ & -21.4627 & $0.0000^{*}$ \\
\hline \multirow[t]{2}{*}{ France } & France_Return & -11.9300 & $0.0000^{*}$ & -20.0238 & $0.0000 *$ \\
\hline & France_ER & -18.0743 & $0.0000^{*}$ & -18.1337 & $0.0000^{*}$ \\
\hline \multirow[t]{2}{*}{ UK } & UK_Return & -6.5191 & $0.0000^{*}$ & -19.9070 & $0.0000 *$ \\
\hline & UK_ER & -16.5986 & $0.0000^{*}$ & -16.5834 & $0.0000 *$ \\
\hline \multirow[t]{2}{*}{ Canada } & Canada_Return & -5.8653 & $0.0000^{*}$ & -24.9417 & $0.0000 *$ \\
\hline & Canada_ER & -19.0444 & $0.0000^{*}$ & -19.0600 & $0.0000 *$ \\
\hline \multirow[t]{2}{*}{ South Korea } & South_Korea_Return & -11.6051 & $0.0000^{*}$ & -20.5550 & $0.0000^{*}$ \\
\hline & South_Korea_ER & -13.3737 & $0.0000^{*}$ & -23.3565 & $0.0000 *$ \\
\hline \multirow[t]{2}{*}{ Brazil } & Brazil_Return & -25.2867 & $0.0000^{*}$ & -24.5413 & $0.0000^{*}$ \\
\hline & Brazil_ER & -20.8581 & $0.0000 *$ & -20.9020 & $0.0000^{*}$ \\
\hline \multirow[t]{2}{*}{ Australia } & Australia_Return & -9.3117 & $0.0000^{*}$ & -24.5785 & $0.0000 *$ \\
\hline & Australia_ER & -16.5283 & $0.0000^{*}$ & -16.7571 & $0.0000 *$ \\
\hline \multirow[t]{2}{*}{ Indonesia } & Indonesia_Return & -17.4479 & $0.0000^{*}$ & -17.7342 & $0.0000^{*}$ \\
\hline & Indonesia_ER & -9.4867 & $0.0000^{*}$ & -18.5274 & $0.0000^{*}$ \\
\hline \multirow[t]{2}{*}{ South Africa } & South_Africa_Return & -9.3498 & $0.0000^{*}$ & -21.1624 & $0.0000^{*}$ \\
\hline & South_Africa_ER & -19.1982 & $0.0000^{*}$ & -19.2172 & $0.0000^{*}$ \\
\hline \multirow[t]{2}{*}{ Singapore } & Singapore_Return & -6.5819 & $0.0000 *$ & -21.4111 & $0.0000 *$ \\
\hline & Singapore_ER & -8.4821 & $0.0000^{*}$ & -18.9219 & $0.0000^{*}$ \\
\hline \multirow[t]{2}{*}{ Morocco } & Morocco_Return & -16.2839 & $0.0000^{*}$ & -16.2883 & $0.0000^{*}$ \\
\hline & Morocco_ER & -11.0218 & $0.0000^{*}$ & -18.6156 & $0.0000 *$ \\
\hline
\end{tabular}

(Source) Authors' calculations. *Significant at the 5\% level. 